\title{
UNDERSTANDING CURRENT AND FUTURE LANDUSE DYNAMICS WITH LAND SURFACE TEMPERATURE ALTERATIONS: A CASE STUDY OF CHANDIGARH
}

\author{
G. Nimish, M. C. Chandan, H. A. Bharath* \\ RCG School of Infrastructure Design and Management, Indian Institute of Technology, Kharagpur \\ *bhaithal@iitkgp.ac.in
}

Commission V, WG V/7

KEY WORDS: Land Use Land Cover, Land Surface Temperature, SLEUTH, Chandigarh

\begin{abstract}
:
Conversion of pervious layer to impervious layer through unplanned urbanization has been a major cause of natural disturbances across the world. However, urbanization is considered a metric that defines the socio-economic value of the city planning and management, if unplanned leads to many serious implications on the environment such as ecological imbalance, increased concentration of pollutants, loss of bio-diversity, etc. A steep increase in population growth, migration to cities and conversion of vegetated lands into other land use classes have been prime factors in expanding urban regions at faster urban growth rates causing sprawl in the periphery and the regions adjacent to the city resulting in increased temperatures. This paper addresses two major facades of urban growth: modelling urban growth pattern with business as usual scenario and understanding the land surface temperature (LST) dynamics with changing patterns of land use. Chandigarh administrative boundary with $10 \mathrm{~km}$ buffer has been considered for this analysis to understand the dynamics and sprawl. The outcome indicates that built-up has increased from 3.7\% in 1991 to $16.16 \%$ in 2017 and the mean LST of the study area has increased by almost $12^{\circ} \mathrm{C}$ (months of March - May). Future prediction performed shows that there would be an extensive outgrowth due to saturated infilling in the core of the city. This analysis would be helpful to planners to
\end{abstract} understand region specific growth and transitions.

\section{Introduction}

Urbanization is a global phenomenon and can be referred as escalation in concrete area of towns and cities as a result of augmented demographic pressure or amalgamation of suburbs into the cities (Ramachandra et al., 2012; Maiti and Agarwal, 2005). According to World Urbanization Prospects, 2014, half of the population lives in urban area globally which will be increased to $2 / 3^{\text {rd }}$ as of 2050 . Urbanization is one of the most important factors for socio-economic development of the city. On the other hand, if certain threshold is crossed, it generates broad impacts on hominids (Dociu and Dunarintu, 2012). Unplanned and uncontrolled urbanization is a result of accelerated growth in terms of extent and intensity that causes fragmented and dispersed development (urban sprawl) (Bharath et al., 2014) and numerous environmental impacts (Mohan et al., 2011). Urbanization has led to intensive alterations in land use patterns (Owoeye and Ibitoye, 2016), as a result, many cities across the globe has been expanding beyond its administrative boundaries in a planned or an unplanned manner (Weerakoon, 2017; Chandan et al., 2017). Every city around the globe is being concretized on the cost of vegetated land, agricultural fields and barren lands (Ramachandra et al., 2017; Pal and Ziaul, 2016; Mallick et al., 2008). LULC modifications as a result of urban sprawl affects the natural flow of resources, degrades air quality and health of residents, causes soil degradation, is one of the key parameters for urban floods and instigates urban heat islands (Siedentop, 2005). LULC changes refers to variation in physical features present on the surface which affects surface albedo, roughness, moisture content, vegetation cover which affects the surface-atmosphere interactions (Yao et al., 2015). LULC alterations such as development of city incorporates transformation of land use with concretized surfaces, reducing the evapotranspiration rates causing sensible heat to increase (Mojolaoluwa et al., 2018); construction and transportation activities causes higher level of emissions in the atmosphere results in elevated concentration of Greenhouse gases $\left(\mathrm{CH}_{4}, \mathrm{CO}_{2}\right.$,

\footnotetext{
* Corresponding author
}

$\mathrm{SO}_{\mathrm{x}}, \mathrm{NO}_{\mathrm{x}}$, etc.) and particulate matters (SPM, $\mathrm{PM}_{10}, \mathrm{PM}_{2.5}$ and $\mathrm{PM}_{1}$ ) that affects the skin temperature of the earth's surface (Land Surface Temperature) (Ministry of Statistic and Programme Implementation, 2015). LST is the basic element of thermal behavior of earth as it affects the intense temperature at the surface of earth (AATSR and SLSTR, 2018). LST and emissivity are two key parameters to comprehend environment and climate change as they govern the surface's upward thermal radiation and thermodynamically influences the atmospheric boundary layer structure (Bento et al., 2017). LST affects the bio-geo-chemical cycle, water cycle, energy interaction in the atmosphere (Jin et al., 2015), regional biodiversity, crop pattern, wind patterns and contributes to climate change at local, regional and global level (Bharath et al., 2013). It is useful in variety of applications such as understanding urban climate pattern, vegetation monitoring (healthy or stressed), hydrological modelling, climate study, understanding urban heat islands, environmental parameter changes, GHG estimations, etc. (Khandelwal et al., 2017; Ramachandra et al., 2017; Ramachandra et al., 2015; Li et al., 2013; Anderson et al., 2008; Running et al., 1994; Li and Becker, 1993; Schmugge and Becker, 1991). Sensor based imaging and analysis has made investigating the urbanization pattern easier for the policy makers and image interpreters (Bharath et al., 2017a; Bharath et al., 2017b; Jasim et al., 2016; Nassar et al., 2014). Assessment of LULC and prediction of likely changes would aid in formulating the strategies and policies for sustainable development in future in terms of housing, transportation (Schnebele et al., 2015), food (Wenban-Smith et al., 2016) and water security (Duh et al., 2008; Usali and Ismail, 2010), health and solid waste management (Li et al., 2012; Mundhe et al., 2017; Glanville and Chang, 2015). Researchers started investigating complex behavior of changing systems with the help of Cellular Automation (CA) in various scientific fields from medicine, forest fire modeling, urban modeling, landscape dynamics and so on (Couclelis, 1985; Torrens, 2000; Ermentrout and Edelstein, 1993; Hernández et al., 2007; Batty and Xie, 1994; Sante et al., 2010). SLEUTH model has evolved from CA model considering both spatial and temporal aspects of urban growth for simulation and prediction. The model gets the name based on layers used as input that is slope, land use, excluded, urban, transportation and hillshade using UNIX operating system (Rafiee et al., 2009). 
Initial designing of the model, its calibration and visualization were demonstrated by Clarke et al., 1997. Since then the open source model has seen successful applications in USA and worldwide along with a dedicated symposium in 2012 (Project Gigalopolis). SLEUTH modeling employs a thorough testing, calibrating and prediction phase using various combinations of coefficient values and scenario files. An effort has been put in this research article to explore detailed linkage between land use, land surface temperature and future urban growth scenario for Chandigarh region.

\section{Study Area}

The study area comprises of Chandigarh municipal boundary along with $10 \mathrm{~km}$ buffer (Figure 1) to understand the sprawl in last three decades. It is known as 'City beautiful' due to its unique concept, modern architecture, urban structures and presence of 1400 green belts/garden/parks. It is the only planned city in India with a population of 10.55 lakhs (Census of India, 2011) with a decadal growth rate of $17.19 \%$. It is joint capital of both states of Punjab and Haryana, and acts as regional center for Himachal Pradesh, Haryana and Punjab. The union territory (UT) has largely developed in terms of infrastructure and economy due to the presence of JLPL industrial area, Rajiv Gandhi Technology Park, Industrial area Phase 1 and 2 within or in periphery of the city. However, due to unsteady urbanization and industrial growth, the UT is developing and needs infrastructure gradations as the demographic limit for which city was planned (half a million people) has already crossed the threshold (Finance Secretary, 2006). Table 1 shows geographic information about the UT.
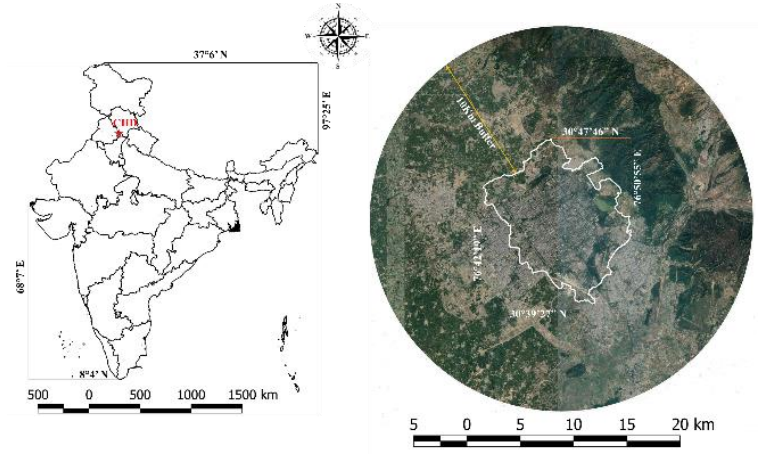

Figure 1: Study area: Chandigarh Municipal Boundary with a $10 \mathrm{~km}$ buffer region

\begin{tabular}{|c|c|}
\hline Area & $\begin{array}{c}114 \mathrm{~km}^{2}\left(+25.42 \mathrm{~km}^{2} \rightarrow \text { Sukhna wildlife }\right. \\
\text { sanctuary })\end{array}$ \\
\hline Latitude & $30^{\circ} 44^{\prime} 14^{\prime \prime} \mathrm{N}$ \\
\hline Longitude & $76^{\circ} 47^{\prime} 14^{\prime \prime} \mathrm{E}$ \\
\hline $\begin{array}{l}\text { Annual } \\
\text { Rainfall }\end{array}$ & $111.4 \mathrm{~cm} /$ year (Monsoon: July - September) \\
\hline Elevation & $350 \mathrm{~m}$ \\
\hline
\end{tabular}

Table 1: Chandigarh: Geographic information

\section{Method}

A six phase process involved in the analysis is as illustrated in Figure 2, which includes - i) Data Acquisition, ii) Feature Extraction, iii) Pre-processing, iv) Land Use Analysis, v) Land Surface Temperature Estimation, vi) Landscape modelling and prediction using SLEUTH model

\subsection{Data Acquisition}

Data was acquired from the sources as mentioned in table 2 below

\begin{tabular}{|l|l|}
\hline \multicolumn{1}{|c|}{ Data } & \multicolumn{1}{c|}{ Source } \\
\hline Temporal Remotes Sensing data & USGS \\
\hline DEM & ASTER DEM \\
\hline $\begin{array}{l}\text { Topographic maps } \\
(1: 50000,1: 250000 \text { scale })\end{array}$ & Survey of India \\
\hline City development plan & $\begin{array}{l}\text { City Development Plan } \\
\text { - Chandigarh }\end{array}$ \\
\hline Secondary data & Google Earth, Bhuvan \\
\hline
\end{tabular}

\subsection{Extraction of features}

City development plan (CDP) was geo-registered using GCPs (ground control points). City municipal boundary (CMB) was then extracted using CDP (mcchandigarh.gov.in), topographic maps (Survey of India) and other supporting datasets. Based on the CMB, a $10 \mathrm{~km}$ circular buffer region was delineated. Important factors supporting the growth such as road network was digitized using classified images, secondary data sources like Google earth and Bhuvan. Slope map and hillshade map was extracted from ASTER DEM (earthexplorer.gov, earthexplorer.usgs.gov). Exclusion layer which resists the growth were derived from CDP map which includes protected areas and water bodies (Ramachandra et al., 2014).

\subsection{Pre-processing}

The remotely sensed data is corrected for geometric and radiometric errors and was resampled using secondary data and topographic maps. All the extracted maps and remotely sensed data was cropped to pertaining area.

\subsection{Land Use Analysis}

Land use analysis is a three-step process that includes generation of false color composite (FCC), Generation of land use class signatures using FCC and Google earth and generation of ground truth data with specific data from field visits and online virtual repositories. Gaussian maximum likelihood classification algorithm was used for land use classification (Bharath et al., 2018). It takes into account the mean, covariance and classifies the data based on probability density function. Data was classified using the signatures created for all the land use classes as shown in Table 3. Accuracy assessment was performed to evaluate the classification, with the help of ground truth data and Google earth. Confusion matrix/error matrix was created and overall accuracy and kappa coefficient was estimated (Shafia et al., 2018).

\begin{tabular}{|c|c|}
\hline $\begin{array}{c}\text { Land Use } \\
\text { Class }\end{array}$ & Land use included in the class \\
\hline Urban & $\begin{array}{c}\text { Impervious/Paved surfaces including } \\
\text { residential and industrial buildings, mixed } \\
\text { pixels containing more than 50\% built-up }\end{array}$ \\
\hline Vegetation & $\begin{array}{c}\text { All the vegetated areas including forest, } \\
\text { parks, nurseries, agricultural fields, etc. }\end{array}$ \\
\hline Water & Lakes, Ponds, Tanks, Reservoirs \\
\hline Others & $\begin{array}{c}\text { Barren agricultural fields, open grounds, } \\
\text { rocks, mining areas, unconstructed roads, etc. }\end{array}$ \\
\hline
\end{tabular}

Table 3: Land use classification categories adopted 


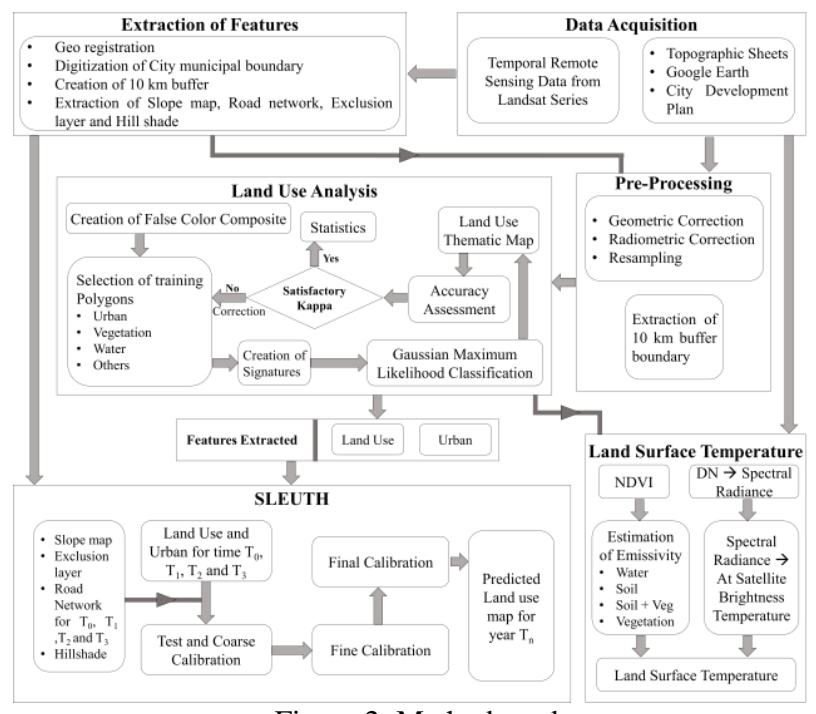

Figure 2: Method used

\subsection{Computation of Land Surface Temperature}

The range $10.4-12.5 \mu \mathrm{m}$ in the electromagnetic spectrum is thermal infrared region which obtains the reflectance from earth's surface. The bands that sense in these regions were used for extraction of land surface temperature. A three step process is used to compute LST

- Generation of Thermal maps: Landsat 8 (operational land imager) and Landsat 5 (Thematic mapper) sensors were used to procure and store thermal data in the form of DN. For Landsat 5, DN value ranges from 0-255 and for Landsat 8, it ranges from 0-65535. Band 6 of Landsat 5 and Band 10 of Landsat 8 was used to quantify Land surface temperature (Kayet et al., 2016).

- Quantification of Emissivity: Emissivity can be computed using NDVI. A threshold value (depending on FCC and Land use map; varies with year) of NDVI was considered to define various land use classes as shown in Table 4.

\begin{tabular}{|c|c|c|}
\hline S. No. & Land use class & NDVI \\
\hline 1. & Water & NDVI $_{\min }$ to NDVI \\
\hline 2. & Soil & NDVI $_{w}$ to NDVIs \\
\hline 3. & Soil + Vegetation & NDVII to NDVIv \\
\hline 4. & Vegetation & NDVI $I_{\text {v }}$ to NDVI \\
max
\end{tabular}

Table 4: NDVI for land use classes

Land use map was reclassified into 4 sections based on NDVI of various classes. Land surface emissivity (LSE) for water, soil and vegetation were considered directly based on literature review (Landsat 8 LST Analysis, 2016) and for combination of soil and vegetation LSE was estimated using eq. 1.

Where,

$$
\varepsilon_{S V}=\varepsilon_{V} P_{V}+\varepsilon_{S}\left(1-P_{V}\right)+C
$$

$\varepsilon s v \rightarrow$ Emissivity of soil + vegetation

$\varepsilon s \rightarrow$ Emissivity of soil

$\varepsilon_{\mathrm{V}} \rightarrow$ Emissivity of vegetation

$\mathrm{Pv} \rightarrow$ Proportion of vegetation or fractional vegetation cover which can be calculated as shown in eq. 2

$\mathrm{C} \rightarrow$ term that takes into account cavity effect due to surface roughness $(\mathrm{C}=0$ for flat surfaces) and is calculated as shown in eq. 3 .

$$
P_{V}=\left(\frac{N D V I-N D V I_{S}}{N D V I_{V}-N D V I_{S}}\right)^{2}
$$

Where,

NDVI $\rightarrow$ NDVI of the pixel under consideration $\mathrm{NDVI}_{\mathrm{S}} \rightarrow \mathrm{NDVI}$ of soil

$$
\begin{aligned}
\text { NDVIv } \rightarrow & \text { NDVI of vegetation } \\
& C=\left(1-\varepsilon_{S}\right) \varepsilon_{V} F\left(1-P_{V}\right)
\end{aligned}
$$

Where,

$\mathrm{F} \rightarrow$ geometrical factor ranging from 0 to 1 depending on surface geometry (usually $\mathrm{F}=0.55$ ).

\begin{tabular}{|c|c|c|}
\hline S. No. & Emissivity & Value \\
\hline 1. & Water $\left(\varepsilon_{W}\right)$ & 0.9910 \\
\hline 2. & Soil $\left(\varepsilon_{S}\right)$ & 0.9668 \\
\hline 3. & Soil + Vegetation $\left(\varepsilon_{S V}\right)$ & $0.9668-0.9863$ \\
\hline 4. & Vegetation $\left(\varepsilon_{V}\right)$ & 0.9863 \\
\hline \multicolumn{2}{|c|}{ Table 5: Emissivity values }
\end{tabular}

- Quantification of LST: It involves a three step process

a) Conversion of $\mathrm{DN}$ into spectral radiance

$$
L_{\lambda}=(\text { Gain X DN })+O f f s e t
$$

Where,

$\mathrm{L} \lambda$ is the spectral radiance; Gain is the band specific multiplicative rescaling factor obtained from metadata; Offset is the band specific additive rescaling factor obtained from metadata.

Gain and Offset is calculated by using eq. 5 and 6 .

$$
\begin{gathered}
\text { Gain }=\frac{L_{\text {max }}-L_{\text {min }}}{2^{n}-1} \\
\text { Offset }=L_{\text {min }}
\end{gathered}
$$

\begin{tabular}{|c|c|c|c|c|c|}
\hline Satellite & $\mathbf{n}$ & $\mathbf{L}_{\max }$ & $\mathbf{L}_{\min }$ & Gain & Offset \\
\hline Landsat 5 & 8 & 15.600 & 1.238 & 0.055 & 1.238 \\
\hline Landsat 8 & 16 & 22.002 & 0.100 & $3.342 \times 10^{-4}$ & 0.100 \\
\hline
\end{tabular}

Table 6: Factors used for conversion of DN values to spectral radiance (Lmax and Lmin obtained from metadata)

b) Conversion of spectral radiance to at-satellite brightness temperature

$$
T_{B}(\text { kelvin })=\frac{K_{2}}{\ln \left(\frac{K_{1}}{L_{\lambda}}+1\right)}-273.15
$$

Where, $K_{1}$ is calibration constant $1 ; K_{2}$ is calibration constant $2 ; T_{B}$ is surface temperature (Kelvin). Table 7 indicates the value of calibration constants.

\begin{tabular}{|c|c|c|}
\hline Satellite & $\boldsymbol{K}_{\boldsymbol{I}}$ & $\boldsymbol{K}_{\boldsymbol{2}}$ \\
\hline Landsat 5 & 607.7600 & 1260.56 \\
\hline Landsat 8 & 774.8853 & 1321.0789 \\
\hline
\end{tabular}

Table 7: Calibration constants

c) At-satellite brightness temperature to LST

As each feature on landscape has different emissivity value, thus the LST can be related to at-satellite brightness temperature by using eq. 8 .

Where,

$$
L S T=\frac{T_{B}}{1+\left(\frac{\lambda T_{B}}{\rho} X \ln (\varepsilon)\right)}
$$

$\lambda$ is the wavelength of the thermal band at which the relative response in maximum with respect to wavelength $(\mu \mathrm{m})$ as shown in Figure 3

$\varepsilon$ is the emissivity of the element

$\rho=\frac{h c}{\sigma}=1.438 \times 10^{-2} \mathrm{mK}$ (Where, h is plank's constant, $\mathrm{c}$ is speed of light, $\boldsymbol{\sigma}$ is Stefan Boltzmann constant).

\subsection{SLEUTH Modelling Method}

Input layers were created, geo-registered to UTM zone 43N WGS 84 coordinate system with three different resolutions: $120 \mathrm{~m}$ (coarse), 60m (fine) and 30m (final). A four-time period urban 
and road layer, two-time period land use layer, single-time period slope, hill shade and excluded layers were standardized and exported as 8-bit grayscale GIF format as depicted in figure 4.

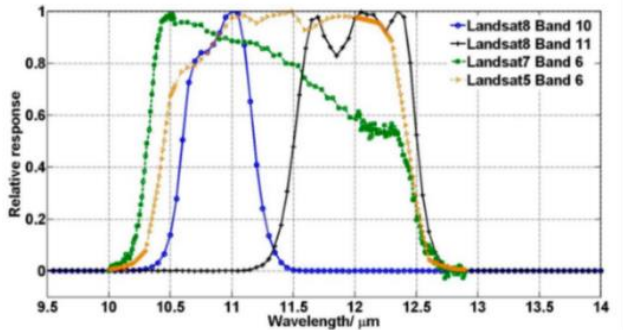

Figure 3: Relative spectral response for Landsat 5, 7 and 8 (Yu et al., 2014)
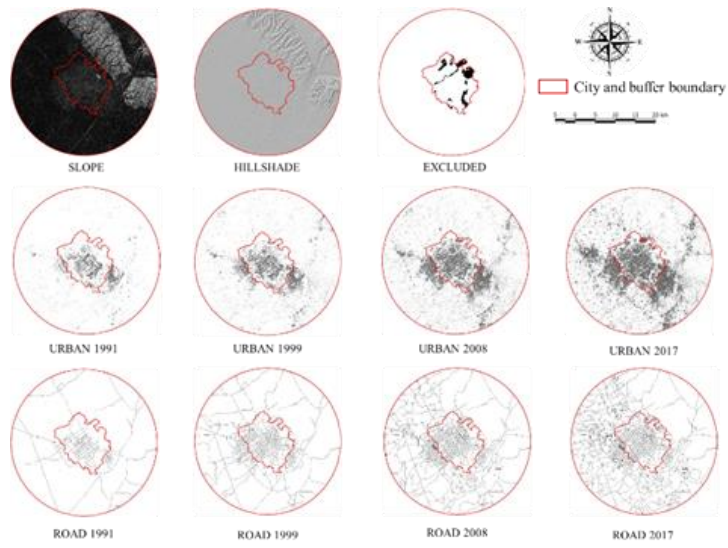

Figure 4: Input layers used for Chandigarh region

A cell's state of urban or non-urban in future is determined by four growth rules: spontaneous growth, new spreading center growth, edge growth and road-influenced growth (Jantz et al., 2004). Input layers, growth rules along with five growth coefficients: dispersion, breed, spread, slope resistance and road gravity forms the core model part initiating test phase, three phases of calibration and one phase prediction. The coefficients have values ranging from 0 to 100 , with least value indicating no influence on growth and highest value suggesting maximum relative importance or impact. Calibration phase can be achieved with two available methods: brute force and genetic algorithm. In this study we adopted brute force calibration method by predetermining step intervals through the entire coefficient space (Goldstein, 2004; Lakshmi et al., 2011). At the end of each calibration phase, model returns 13 least square regression metrics as a measure of goodness of fit to check model accuracy and consistency. Based on the literature, we employ six metrics to assess model accuracy: Compare, Population, Edges, Clusters, Cluster size and Lee-salee (Jantz et al., 2004; Dezhkam et al., 2014; Silva and Clarke, 2002). To derive best set of parameters, the coefficient ranges in different calibration phases were narrowed down by sorting Lee-salee metric values (Dezhkam et al., 2014). To explore complete coefficient space in all calibration phases, Monte Carlo stochastic method was employed with an advantage of time effective process. Prediction phase followed by calibration phase uses historical trends and unique coefficient values obtained from final calibration.

\section{Results and Discussions}

\subsection{Land Use Analysis}

Temporal land use analysis was performed and the results obtained are as shown in Figure 5 and Figure 6. Urban and vegetation class has shown a rise of $336.76 \%$ and $84.69 \%$ respectively. The water body has declined in 1999 and then later has been increasing. All the land use changes have been occurring on the cost of others class. The major urban development during the study period has happened in the city of Panchkula, Sahibzada Ajit Singh nagar, Kharar, Khanpur, Jujhar nagar, Tira and some pockets of village in the western part of study area (Kurara, Dhurali, Saneta, Chudiala, Saidpur, Magar, Jhanjheri, Badali, Bhago majra, etc.). The sectors within the UT has also experienced densification. The vegetation near Karoran, Sukhteri and Manakpur kholgaman has been increasing due to plantation activities.

The major stimulators of the incessant rise in built-up and vegetated areas during the study period are increased employment opportunities, high profile living standards, strong economic and administrative growth, greener living environment, etc. All these contribute to the development and densification of nearby villages that has led to huge number of settlements coming up along the transport corridors. A park, garden in terms of vegetation and a tank, pond or a small water body can be observed near almost all the settlements. Overall accuracy and kappa coefficient was estimated to be in the range of $90.75 \%$ to $94.10 \%$ and 0.75 to 0.86 respectively.

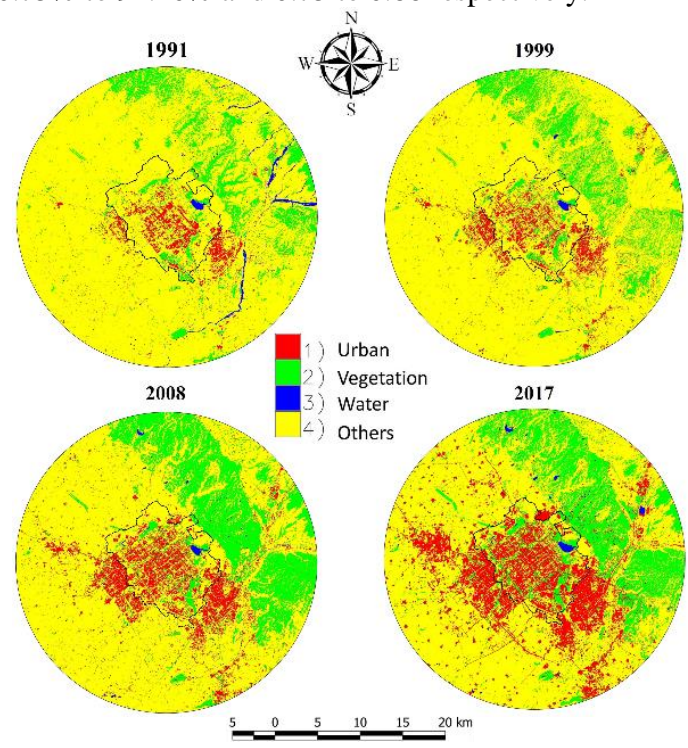

Figure 5: Temporal Land Use Analysis

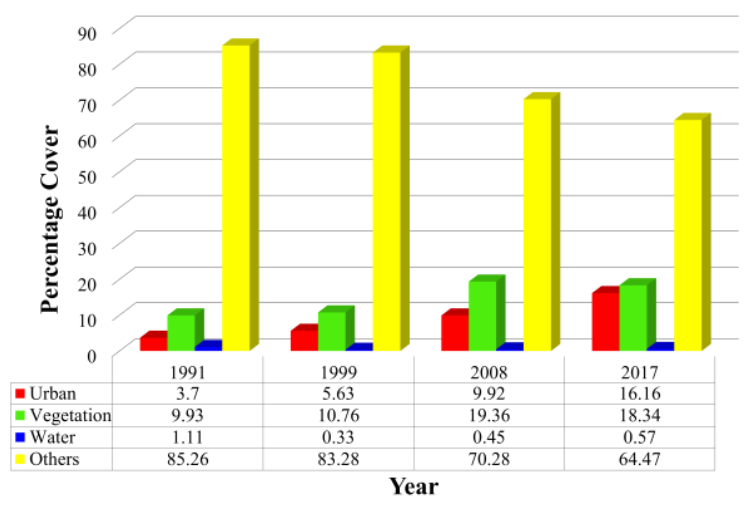

Figure 6: Percentage cover by each land use class during the study period

\subsection{Land Surface Temperature}

Land surface temperature of Chandigarh municipal boundary was quantified considering $10 \mathrm{~km}$ buffer as shown in Figure 7. Table 8 illustrates temperature statistics for the study region. The mean temperature of the city was found to be $30-34^{\circ} \mathrm{C}$ during the study period (April and May). The minimum and the maximum 
temperature of the region has a rise by $11^{\circ} \mathrm{C}$. The concretization in Chandigarh has increased from $3.70 \%$ in 1991 to $16.61 \%$ in 2017 which has led to rise in the mean surface temperature for the urban class to increase by $11.31^{\circ} \mathrm{C}$. Even though the vegetation cover of the region has increased but the mean surface temperature of vegetation class has been increased from $23.97^{\circ} \mathrm{C}$ to $36.08^{\circ} \mathrm{C}$. The reason lying behind it can be increased agricultural lands and plantation of some non-native species in the forest region of Karoran. The year 1991 shows a high LST for water class because the river Kaushalya (Ghaggar) has very less water at the time of image acquisition. In 2017 the region is classified as others category due to complete drying of the river (during data acquisition). The mean surface temperature of water class has increased from $26.35^{\circ} \mathrm{C}$ to $32.62^{\circ} \mathrm{C}$ which is due to the decrease in the depth of water as well as pollution in water bodies. The mean temperature of others category has been increased by $12.07^{\circ} \mathrm{C}$.

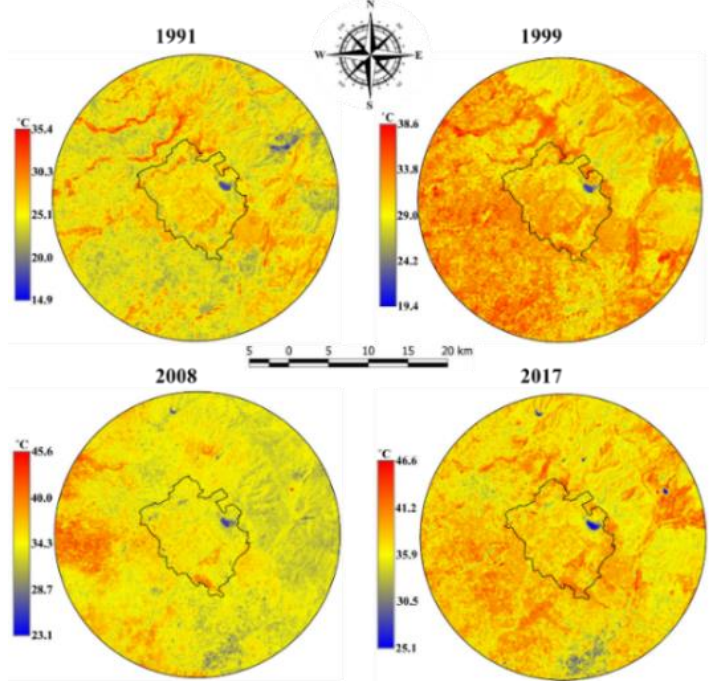

Figure 7: Temporal Land Surface temperature analysis for Chandigarh with $10 \mathrm{~km}$ buffer

Within the Chandigarh municipal boundary, open area near Daddu majra colony, Industrial area phase I and II, and Chandigarh airport shows the maximum temperature $\left(42-44^{\circ} \mathrm{C}\right)$. The central business district of Chandigarh (Sector 17) has a temperature of $35-39^{\circ} \mathrm{C}$. Other built-up region in the city shows moderate temperatures. Patiali Rao reserved forest shows less temperature and Sukhana lake shows the minimum temperature $\left(\sim 25^{\circ} \mathrm{C}\right)$ in the core region. In buffer region, dried river bed of Kaushalya river shows the maximum temperature. Barren agricultural fields near Parchh and open areas next to Mullanpur Garibdass, Bahalpur, Siami pur, Nagliyan and Kherpur shows a high temperature. Chattbir zoo in the Southern part of the region shows a moderate surface temperature ranging from $32-34^{\circ} \mathrm{C}$. Agricultural fields near Bahora, Paragpuri, Bahori and some agricultural field in the vicinity of Ghaggar river near Shatabgarh region shows low surface temperature $\left(28-30^{\circ} \mathrm{C}\right)$. Minimum temperature in the buffer region is exhibited by the stagnant water present next to Kaushalya dam.

Coefficient of variation (COV) for Chandigarh municipal boundary was considered to understand how temperature varies within a single land use classes. Water body shows the maximum $\mathrm{COV}$, thus it can be inferred that the water bodies present in the city have huge variation in depths. Others and vegetation class shows a moderate value signifying the presence of similar kind of open fields and vegetation type. The COV for urban is less showing that the construction material does not vary. To understand how is land use correlated to temperature, a profile graph for Chandigarh municipal boundary was created as shown in Figure 8. Three transacts were considered A-B, C-D and E-F. Considering transact $\mathrm{A}$ to $\mathrm{B}$, initially the graph shows a high value due to the presence of built up in HBC.

The graph then shows a dip due to the presence of vegetated area near Dhanas. The graph then shows a moderate value due to the presence of built up along with some vegetation (Sector 25, 24, $23,22,21,20,30$ and 29). Then the peak is due to the presence of MW area where it is pure built up.

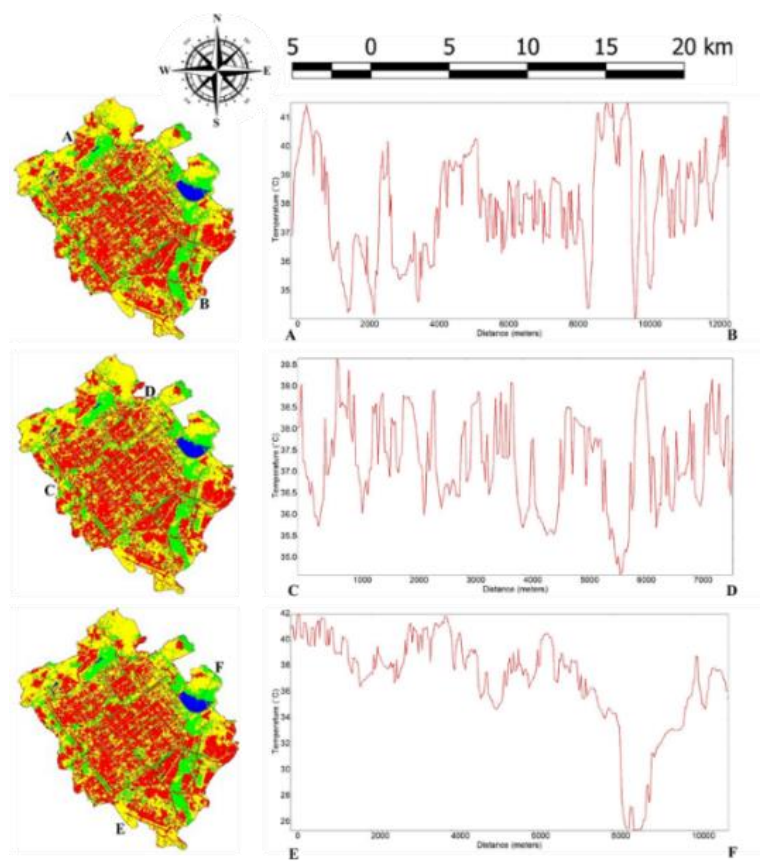

Figure 8: Temperature profile graph for Chandigarh

\begin{tabular}{|c|c|c|c|c|c|c|}
\hline Year & $\begin{array}{c}\text { Land } \\
\text { use } \\
\text { class }\end{array}$ & $\begin{array}{c}\text { Min. } \\
\text { Temp. } \\
\left({ }^{\circ} \mathbf{C}\right)\end{array}$ & $\begin{array}{c}\text { Max. } \\
\text { Temp. } \\
\left.{ }^{\circ} \mathbf{C}\right)\end{array}$ & $\begin{array}{c}\text { Mean } \\
\text { Temp. } \\
\left({ }^{\circ} \mathbf{C}\right)\end{array}$ & $\begin{array}{c}\text { Stan } \\
\text { dard } \\
\text { Devia } \\
\text { tion }\end{array}$ & $\begin{array}{c}\text { Coeffici } \\
\text { ent of } \\
\text { variatio } \\
\text { n }(\%)\end{array}$ \\
\hline \multirow{4}{*}{1991} & Urban & 17.53 & 33.73 & 27.44 & 1.52 & 5.53 \\
\cline { 2 - 7 } & $\begin{array}{c}\text { Veget } \\
\text { ation }\end{array}$ & 14.89 & 31.24 & 23.96 & 1.43 & 5.99 \\
\cline { 2 - 7 } & Water & 17.70 & 34.14 & 26.34 & 3.43 & 13.04 \\
\cline { 2 - 7 } & Others & 15.32 & 35.37 & 25.70 & 2.06 & 8.02 \\
\hline \multirow{4}{*}{$\mathbf{1 9 9 9}$} & Urban & 19.39 & 38.19 & 32.43 & 1.51 & 4.67 \\
\cline { 2 - 7 } & $\begin{array}{c}\text { Veget } \\
\text { ation }\end{array}$ & 23.82 & 38.59 & 29.46 & 1.59 & 5.40 \\
\cline { 2 - 7 } & Water & 21.73 & 38.59 & 27.72 & 4.2 & 15.40 \\
\cline { 2 - 7 } & Others & 19.85 & 38.59 & 31.89 & 1.85 & 5.80 \\
\hline \multirow{4}{*}{2008} & Urban & 23.05 & 45.58 & 35.21 & 1.70 & 4.83 \\
\cline { 2 - 7 } & $\begin{array}{c}\text { Veget } \\
\text { ation }\end{array}$ & 27.32 & 43.67 & 33.20 & 1.37 & 4.15 \\
\cline { 2 - 7 } & Water & 24.78 & 44.82 & 31.24 & 3.59 & 11.51 \\
\cline { 2 - 7 } & Others & 26.48 & 45.20 & 34.72 & 2.07 & 5.97 \\
\hline \multirow{4}{*}{2017} & Urban & 27.71 & 46.64 & 38.75 & 1.40 & 3.61 \\
\cline { 2 - 7 } & $\begin{array}{c}\text { Veget } \\
\text { ation }\end{array}$ & 27.37 & 44.19 & 36.08 & 1.35 & 3.73 \\
\cline { 2 - 7 } & Water & 25.06 & 45.21 & 32.61 & 4.76 & 14.61 \\
\cline { 2 - 7 } & Others & 28.22 & 46.05 & 37.77 & 2.08 & 5.50 \\
\hline
\end{tabular}

Table 8: Temperature statistics for Chandigarh with $10 \mathrm{~km}$ buffer

Another dip is due to the presence of Dariya reserved forest and then the moderate value is due to the presence of open field in Raipur kalan. Transact $\mathrm{C}$ to $\mathrm{D}$, due to the presence of urban areas with vegetation (Sector 41B, 37, 24D, 12 and Audit pool colony), vegetation only (near sector 42A) and open areas (Sector 42D) a 
continuous peaks and valleys are obtained. In Transact $\mathrm{E}$ to $\mathrm{F}$, the temperature shows high peak due to the presence of Chandigarh airport, Industrial area phase 1 and 2, Sector 26 (built up). Towards the end a huge dip is due to the presence of Sukhna Lake and Lake Forest reservoir. In the end of transact E-F, due to the presence of barren agricultural fields the temperature profile again shows high temperature.

\subsection{SLEUTH Modelling}

Results of calibration phase with range values and step values are listed in Table 9. Chandigarh region noticed medium slope resistance attributed to lower Shivalik range in the north eastern part of the city (figure 4). Since the city is planned well both in terms of spatial and temporal aspects, the diffusion and breed coefficients are observed to be less. High spread and road gravity values indicate further the city would grow in a radiating trend from existing urban centers and majority of the urban areas concentrated along major roads (SH 12A, NH 22, 64, 73 and 95, DLF Mallanpur - Kurali road). Model fit measures such as population, urban edges, cluster and cluster size were nearing unity indicated excellent agreement between existing urban area taken over control years 1991, 1999, 2008 and 2017 and predicted urban area. The prediction was performed for 2026 . Predicted output for Chandigarh region is as shown in figure 9. Statistics reveal the region had $16.61 \%$ or $169.05 \mathrm{~km}^{2}$ of urban cover in 2017 soared to $41.44 \%$ or $421.76 \mathrm{~km}^{2}$ in 2026.

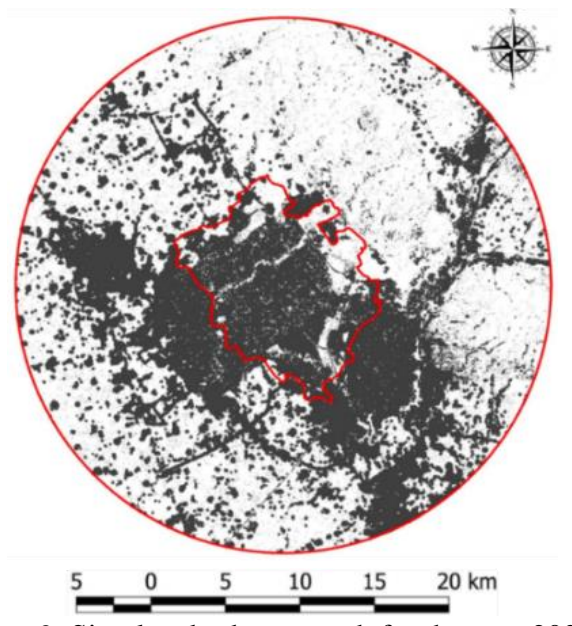

Figure 9: Simulated urban growth for the year 2026 Chandigarh region

\begin{tabular}{|c|c|c|c|c|c|c|c|c|}
\hline \multicolumn{7}{|c|}{ Calibration Phase } \\
\hline \multirow{2}{*}{ Coarse } & \multicolumn{2}{|c|}{ Fine } & \multicolumn{2}{c|}{ Final } & \multicolumn{2}{c|}{ Prediction } \\
\cline { 2 - 9 } & Rang & Step & Range & Step & Range & Step & $\begin{array}{c}\text { Value } \\
\text { based } \\
\text { on } \\
\text { Lee- } \\
\text { Salee }\end{array}$ & $\begin{array}{c}\text { Value } \\
\text { based } \\
\text { on } \\
\text { avg } \\
\text { log }\end{array}$ \\
\hline Diffusion & $\begin{array}{c}0 \text { to } \\
100\end{array}$ & 25 & 1 to 25 & 5 & 1 to 5 & 1 & 1 & 6 \\
\hline Breed & $\begin{array}{c}0 \text { to } \\
100\end{array}$ & 25 & 1 to 25 & 5 & 1 to 5 & 1 & 2 & 77 \\
\hline Spread & $\begin{array}{c}0 \text { to } \\
100\end{array}$ & 25 & 50 to 75 & 5 & $\begin{array}{c}50 \text { to } \\
55\end{array}$ & 1 & 50 & 96 \\
\hline Slope & $\begin{array}{c}0 \text { to } \\
100\end{array}$ & 25 & 1 to 25 & 5 & $\begin{array}{c}15 \text { to } \\
20\end{array}$ & 1 & 17 & 28 \\
\hline $\begin{array}{c}\text { Road } \\
\text { gravity }\end{array}$ & $\begin{array}{c}0 \text { to } \\
100\end{array}$ & 25 & 50 to 75 & 5 & $\begin{array}{c}60 \text { to } \\
65\end{array}$ & 1 & 64 & 42 \\
\hline
\end{tabular}

\begin{tabular}{|c|c|c|c|c|}
\hline $\begin{array}{c}\text { Monte } \\
\text { Carlo } \\
\text { iterations }\end{array}$ & 5 & 8 & 10 & \multirow{2}{*}{100} \\
\hline \multicolumn{5}{|c|}{ Model Fit Measures } \\
\hline Compare & 0.623 & 0.661 & 0.661 & \\
\hline Population & 0.985 & 0.988 & 0.988 & \multirow{2}{*}{-- } \\
\hline Edges & 0.999 & 1.000 & 1.000 & \multirow{2}{*}{0.933} \\
\hline Clusters & 0.999 & 0.998 & 0.899 & \\
\hline $\begin{array}{c}\text { Cluster } \\
\text { size }\end{array}$ & 0.972 & 0.961 & 0.393 & \\
\hline Lee-Salee & 0.400 & 0.398 & 0.969 \\
\hline
\end{tabular}

Table 9: Summary of calibration results and fit statistics for Chandigarh

\section{Conclusion}

The study signifies one of the wide range of applications that can be performed using remotely sensed data. Studies on LULC and LST changes, their correlation and how they affect the climate has been a area of interest. The city of Chandigarh was planned for a population of half a million which has already become 1.55 million (as of 2011, Census of India) leading to sprawling. The planned city is now experiencing a higher temperature as inferred by the results. Results shows that during the study period, growth of $336.76 \%$ in urban area has led to a mean surface temperature rise of $12^{\circ} \mathrm{C}$. The city has been experiencing urban growth in the center as well as in north-west and southeast direction. The major concretization happened in Sahibzada Ajit Singh nagar and Panchkula that are in vicinity of the city boundary. Plantation activities were observed in the Sukhteri and Karoran region (hilly terrain). The study helps to correlate the change in LST with LU alterations. Urban area and others category shows the high, vegetation shows moderate while water shows lowest mean surface temperature. The study shows how water body and vegetation can help in regulating the microclimate of the region and why having green belts is important. Various schemes from Government of India such as Smart City Mission, Housing for all by 2022, JNNURM, AMRUT, National Urban Livelihood Mission, HRIDAY, etc. has made studying and predicting future landscape patterns imperative. Thus, SLEUTH model was used in the study that considers various drivers and constraints to predict land use by 2026 . Validation of SLEUTH model was carried out and it was found to be a good prediction model for urban studies. The model predicted maximum urban growth to be in or around SH 12A, NH 22, 64, 73 and 95, DLF Mallanpur Kurali road.

Although, the city of Chandigarh is well eastablished, planned and managed uptill now, few problems such as higher temperature has already instigated. Thus, planning according to the current scenerio has to be done and strict policies has to be formulated and implemented for having a sustainable and effective development, thus, counteracting on the growing urban population needs.

\section{Acknowledgements}

We are grateful to SERB, India, Ministry of Science and Technology, Government of India, SRIC-Indian Institute of Technology Kharagpur and DST-Govt. of West Bengal for the financial and infrastructure support. We thank (i) United States Geological Survey and (ii) National Remote Sensing Centre (NRSC Hyderabad) for providing temporal remote sensing data. 


\section{References}

AATSR and SLSTR. LST Portal: Welcome to the AATSR/SLSTR Land Surface Temperature Portal, 2018. Accessed on: April 24, 2018. Retrieved from: http://lst.nilu.no/

Anderson, M. C., Norman, J. M., Kustas, W. P., Houborg, R., Starks, P. J., and Agam, N., 2008. A thermal-based remote sensing technique for routine mapping of land-surface carbon, water and energy fluxes from field to regional scales. Remote Sensing of Environment, 112(12), pp. 4227-4241.

Batty, M. and Xie, Y., 1994. From cells to cities. Environment and planning B: Planning and design, 21(7), pp. 31-48.

Bento, V. A., DaCamara, C. C., Trigo, I. F., Martins, J., and Duguay-Tetzlaff, A., 2017. Improving Land Surface Temperature Retrievals over Mountainous Regions. Remote Sensing, 9(1), 38, pp. 1-13.

Bharath, H. A., Chandan, M. C., Vinay, S., and Ramachandra, T. V., 2017a. Modelling urban dynamics in rapidly urbanising Indian cities. The Egyptian Journal of Remote Sensing and Space Science.

Bharath, H. A., Chandan, M. C., Vinay, S., and Ramachandra, T. V., 2017b. Intra and Inter Spatio-Temporal Patterns of Urbanisation in Indian Megacities. International Journal of Imaging and Robotics ${ }^{\mathrm{TM}}, 17(2)$, pp. 68-86.

Bharath, H. A., Vinay, S., and Ramachandra, T. V., 2014. Prediction of spatial patterns of urban dynamics in Pune, India. In India Conference (INDICON), 2014 Annual IEEE. pp. 1-6.

Bharath, H. A., Vinay, S., Chandan, M. C., Gouri, B. A., and Ramachandra, T. V., 2018. Green to gray: Silicon Valley of India. Journal of Environmental Management, 206, pp. 12871295.

Bharath, S., Rajan, K. S., and Ramachandra, T. V., 2013. Land surface temperature responses to land use land cover dynamics. Geoinformatics Geostatistics: An Overview, 1(4).

Bhuvan, 2018. Bhuvan: Virtual Globe, 2018. Accessed on: March 16, 2018. Retrieved from: https://www.bhuvan.nrsc.gov.in.

Chandan, M. C., Aishwarya, N., Nimish, G. and Bharath, H. A., 2017. Multi temporal urban growth characterization using Geospatial technologies. In proceedings of $38^{\text {th }}$ Asian Conference of Remote Sensing - 2017, 23 - 27 October.

Clarke, K. C., Hoppen, S., and Gaydos, L., 1997. A selfmodifying cellular automaton model of historical urbanization in the San Francisco Bay area. Environment and Planning B: Planning and Design, 24(2), pp. 247-261.

Couclelis, H., 1985. Cellular worlds: a framework for modeling micro-macro dynamics. Environment and planning A, 17, pp. 585-596.

Dezhkam, S., Amiri, B.J., Darvishsefat, A.A. and Sakieh, Y., 2014. Simulating the urban growth dimensions and scenario prediction through sleuth model: A case study of Rasht County, Guilan, Iran. GeoJournal, 79(5), pp. 591-604.

Dociu, M., and Dunarintu, A., 2012. The socio-economic impact of urbanization. International Journal of Academic Research in Accounting, Finance and Management Sciences, 2(1), pp. 47-52. Duh, J. D., Shandas, V., Chang, H., and George, L. A., 2008. Rates of urbanisation and the resiliency of air and water quality. Science of the total environment, 400(1-3), pp. 238-256.
Earth Explorer, 2018. USGS: Earth Explorer, 2018. Accessed on: March 13, 2018. Retrieved from: https://earthexplorer.usgs.gov/

Ermentrout, G. B., and Edelstein-Keshet, L., 1993. Cellular automata approaches to biological modeling. Journal of Theoretical Biology, 160(1), pp. 97-133.

Finance Secretary. 2006. City Development Plan - Chandigarh. Accessed on: April 25, 2018. Retrieved from: http://mcchandigarh.gov.in/cdp.pdf

Glanville, K., and Chang, H. C., 2015. Remote sensing analysis techniques and sensor requirements to support the mapping of illegal domestic waste disposal sites in Queensland, Australia. Remote Sensing, 7(10), pp. 13053-13069.

Goldstein, N. C., 2004. Brains vs. Brawn - Comparative strategies for the calibration of a Cellular Automata - Based Urban Growth Model. GeoDynamics, pp. 249-272.

Google Earth, 2018. A virtual globe, 2018. Accessed on: March 15, 2018. Retrieved from: https://www.google.com/earth/

Hernández Encinas, L., Hoya White, S., Martín Del Rey, A., and Rodríguez Sánchez, G., 2007. Modelling forest fire spread using hexagonal cellular automata. Applied Mathematical Modelling, 31(6), pp. 1213-1227.

Jantz, C. A., Goetz, S. J., and Shelley, M. K., 2004. Using the SLEUTH urban growth model to simulate the impacts of future policy scenarios on urban land use in the Baltimore-Washington metropolitan area. Environment and Planning B: Planning and Design, 31(2), pp. 251-271.

Jasim, M. A., Shafri, H. Z. M., Hamedianfar, A., and Sameen, M. I., 2016. Land transformation assessment using the integration of remote sensing and GIS techniques: a case study of Al-Anbar Province, Iraq. Arabian Journal of Geosciences, 9(15), p. 667.

Jin, M., Li, J., Wang, C., and Shang, R., 2015. A practical splitwindow algorithm for retrieving land surface temperature from Landsat- 8 data and a case study of an urban area in China. Remote sensing, 7(4), pp. 4371-4390.

Kayet, N., Pathak, K., Chakrabarty, A., \& Sahoo, S., 2016. Spatial impact of land use/land cover change on surface temperature distribution in Saranda Forest, Jharkhand. Modeling Earth Systems and Environment, 2(3), 127, pp. 1-10.

Khandelwal, S., Goyal, R., Kaul, N. and Mathew, A., 2018. Assessment of land surface temperature variation due to change in elevation of area surrounding Jaipur, India. The Egyptian Journal of Remote Sensing and Space Science, 21(1), pp. 87-94.

Lakshmi, K. N., Sawant, N. G., and Kumar, S., 2011. Forecasting urban growth based on GIS, RS and SLEUTH model in Pune metropolitan area. International Journal of Geomatics and Geosciences, 2(2), pp. 568-579.

Landsat 8 LST Analysis, 2016. Automated generation of Land Surface Temperature estimates. Accessed on: March 28, 2018. Retrieved from: https://datahub.cmap.illinois.gov/.

Li, X., Wang, C., Zhang, G., Xiao, L., and Dixon, J., 2012. Urbanisation and human health in China: spatial features and a systemic perspective. Environmental Science and Pollution Research, 19(5), pp. 1375-1384.

Li, Z. L., and Becker, F., 1993. Feasibility of land surface temperature and emissivity determination from AVHRR data. Remote Sensing of Environment, 43(1), pp. 67-85. 
Li, Z. L., Tang, B. H., Wu, H., Ren, H., Yan, G., Wan, Z., Trigo, I. F. and Sobrino, J. A., 2013. Satellite-derived land surface temperature: Current status and perspectives. Remote Sensing of Environment, 131, pp. 14-37.

Maiti, S. and Agrawal, P.K., 2005. Environmental degradation in the context of growing urbanization: a focus on the metropolitan cities of India. Journal of Human Ecology, 17(4), pp. 277-287.

Mallick, J., Kant, Y., and Bharath, B. D., 2008. Estimation of land surface temperature over Delhi using Landsat-7 ETM+. J. Ind. Geophys. Union, 12(3), pp. 131-140.

Ministry of Statistics and Programme Implementation, Government of India, 2015. Statistics related to Climate change - India 2015. Accessed on: April 25, 2018. Retrieved from: http://www.mospi.gov.in/sites/default/files/publication_reports/ climateChangeStat2015.pdf

Mohan, M., Pathan, S. K., Narendrareddy, K., Kandya, A., and Pandey, S., 2011. Dynamics of urbanization and its impact on land-use/land-cover: a case study of megacity Delhi. Journal of Environmental Protection, 2(09), p. 1274.

Mojolaoluwa, T. D., Emmanuel, O. E. and Kazeem, A. I., 2018. Assessment of thermal response of variation in land surface around an urban area. Modelling Earth Systems and Environment. 4, pp. 535-553

Mundhe, N., Jaybhaye, R., and Dorik, B., 2014. Assessment of municipal solid waste management of Pune city using geospatial tools. International Journal of Computer Applications, 100(10), pp. 24-32.

Nassar, A. K., Blackburn, G. A., and Whyatt, J. D., 2014. Developing the desert: The pace and process of urban growth in Dubai. Computers, Environment and Urban Systems, 45, pp. 5062.

Owoeye, J. O., and Ibitoye, O. A., 2016. Analysis of Akure Urban Land Use Change Detection from Remote Imagery Perspective. Urban Studies Research, 2016, pp. 1-9.

Pal, S., and Ziaul, S., 2017. Detection of land use and land cover change and land surface temperature in English Bazar urban centre. The Egyptian Journal of Remote Sensing and Space Science, 20(1), pp. 125-145.

Project Gigalopolis: Urban and Land Cover Modeling, 2018. Accessed on 07/02/2018. Retrieved from: www.ncgia.ucsb.edu/projects/gig/project_gig.htm.

Rafiee, R., Mahiny, A. S., Khorasani, N., Darvishsefat, A. A., and Danekar, A., 2009. Simulating urban growth in Mashad City, Iran through the SLEUTH model (UGM). Cities, 26(1), pp. 1926.

Ramachandra, T.V., Vishnu, B., Gouri, K., Bharath, H. A. and Han, S.S., 2017. Economic disparity and $\mathrm{CO}_{2}$ emissions: The domestic energy sector in Greater Bangalore, India, Renewable and Sustainable Energy Reviews, 67, pp. 1331-1344.

Ramachandra, T.V., Bharath H. A. and Shreejith, K., 2015. GHG footprint of Major cities in India, Renewable and Sustainable Energy Reviews. 44, pp.473-495.

Ramachandra, T. V., Bharath, H. A., and Sanna, D. D., 2012. Insights to urban dynamics through landscape spatial pattern analysis. International Journal of Applied Earth Observation and Geoinformation, 18, pp. 329-343.
Ramachandra, T. V., Bharath, S., and Nimish, G., 2018. Modelling landscape dynamics with LST in protected areas of Western Ghats, Karnataka. Journal of environmental management, 206, pp. 1253-1262.

Ramcachandra, T. V., Bharath, H. A., Vinay, S., Kumar, U., Venugopal, K. R., and Joshi, N. V., 2016. Modelling and Visualization of Urban Trajectory in 4 cities of India. Proceedings of IISc-ISROSTC, Indian Institute of Science, Bangalore. 2017, 7-8 January.

Running, S. W., Justice, C. O., Salomonson, V., Hall, D., Barker, J., Kaufmann, Y. J., Strahler, A. H., Huete, A., Muller, J.P., Vanderbilt V., Wan, Z. M., Teillet, P. and Carneggie, D., 1994. Terrestrial remote sensing science and algorithms planned for EOS/MODIS. International journal of remote sensing, 15(17), pp. 3587-3620.

Santé, I., García, A. M., Miranda, D., and Crecente, R., 2010. Cellular automata models for the simulation of real-world urban processes: A review and analysis. Landscape and Urban Planning, 96(2), pp. 108-122.

Schmugge, T. J., and Becker, F., 1991. Remote sensing observations for the monitoring of land-surface fluxes and water budgets. In Land Surface Evaporation (pp. 337-347). Springer, New York, NY.

Schnebele, E., Tanyu, B. F., Cervone, G., and Waters, N., 2015 Review of remote sensing methodologies for pavement management and assessment. European Transport Research Review, 7(2), 2, pp. 1-19

Shafia, A., Nimish, G. and Bharath, H. A., 2018. Dynamics of Land Surface Temperature with changing land use: Building a climate resilient smart city. In proceeding of $3^{\text {rd }}$ International Conference for Convergence in Technology - 2018, April 6-8.

Survey of India, 2018. Survey of India. Accessed on: March 20, 2018. Retrieved from: http://surveyofindia.gov.in.

UNDESA, 2015. World urbanization prospects: The 2014 revision. United Nations Department of Economics and Social Affairs, Population Division: New York, NY, USA. Retrieved from: https://esa.un.org/unpd/wup/publications/files/wup2014report.pdf

Usali, N., and Ismail, M. H., 2010. Use of remote sensing and GIS in monitoring water quality. Journal of Sustainable Development, 3(3), pp. 228-238.

Weerakoon, K., 2017. Analysis of Spatio-Temporal Urban Growth Using GIS Integrated Urban Gradient Analysis; Colombo District, Sri Lanka. American Journal of Geographic Information System, 6(3), pp. 83-89.

Wenban-Smith, H., Faße, A., and Grote, U., 2016. Food security in Tanzania: the challenge of rapid urbanisation. Food Security, 8(5), pp. 973-984.

Yao, X., Wang, Z., and Wang, H.,2015. Impact of urbanization and land-use change on surface climate in middle and lower reaches of the Yangtze River, 1988-2008. Advances in Meteorology, 2015. Article ID: 395094, pp. 1-10.

Yu, X., Guo, X., and Wu, Z., 2014. Land surface temperature retrieval from Landsat 8 TIRS - Comparison between radiative transfer equation-based method, split window algorithm and single channel method. Remote Sensing, 6(10), pp. 9829-9852. 